\title{
Tutkimus muikun eräistä elintarviketeknologisista ominaisuuksista
}

\author{
Jorma J. Laine, Virve Raussi ja Pekka Koivistoinen \\ Elintarvikekemian ja -teknologian laitos (EKT) Helsingin yliopisto, 00710 \\ Helsinki 71
}

\section{On food-technological quality of muikku (Coregonus albula L.)}

Jorma J. Laine, Vikve Raussi and Pekka Koivistoinen

Debartment of Food Chemistry and Technology, University of Helsinki, 00710, Helsinki 71

\begin{abstract}
The purpose of the study was to examine the fresh keeping quality, size distribution, and gutting waste of muikku (Coregonus albula L.). After catch muikku (Coregonus albula L.) kept bacteriologically acceptable for $24-36$ hours at $+4^{\circ} \mathrm{C}$ and for less than 24 hours at $+10^{\circ} \mathrm{C}$. Consequently, this fish shoud be transported immediately from the fisherman to the processing plant and the transportation should be done under cool conditions or the fishes should be iced.

Microbiological spoilage preceeded always the spoilage of fats. TBA-value was not a suitable criterium for quality in this study.

By seinefishing in each of the three lakes of the study more than $60 \%$ of the catch consisted of fishes from 10 to 16 grams. This sizecategory is very suitable raw material for processing. The average gutting waste was $25.6 \%$.
\end{abstract}

Muikun (Coregonus albula L.) esiintymisalueen muodostavat ensisijaisesti Itämerta ympäröivät maat. Suomessa muikku kuuluu lähes kaikkien suurten ja keskisuurten järvien kalastoon. Matalissa järvissä veden korkea lämpötila kesäisin on esiintymistä rajoittava tekijä. Pohjois-Lapin vesistöistä muikku puuttuu.

Muikkua pidetään kylmän veden kalana ja alusveden kesälämpötilan tulee alittaa $15^{\circ} \mathrm{C}$ :tta. Suomessa ovat muikun istutukset onnistuneet hyvin keskisyvyydeltään $10 \mathrm{~m}: \mathrm{n}$ järvissä, mutta epäonnistuneet järvissä, joiden keskisyvyys on alle $6 \mathrm{~m}$.

Muikku ei ole vaelluskala, mutta se liikkuu parvissa syvänteiden ja matalan veden välillä lämpötilan, ravinnon ja kudun ollessa määräävinä tekijöinä tässä suhteessa. Muikku on syyskutuinen kala, joka suorittaa kutuvaelluksensa mataliin rantavesiin veden jäähtyessä $6-7^{\circ} \mathrm{C}$ :een. Tätä korkeammissa lämpötiloissa muikku ei kude (Järvi 1947). Kutualueella pohjan tulee olla mahdollisimman puhdas ja kiinteä, joko hiekkaa, soraa tai myös kovaa hietaa tai savea. Kutusyvyys vaihtelee $1-5 \mathrm{~m}: n$ välillä järvistä riippuen (NIssıneN 1972). 
Muikkukantoja on erittäin paljon. Kantojen runsaus vaihtelee vuodesta toiseen. Vuosiluokkakatojen syy on useinkin riippuvainen järven lämpötiloista. Jos kuoriutuminen tapahtuu veden korkeasta lämpötilasta johtuen liian aikaisin, ravinnoksi sopivaa planktonia ei ole ehtinyt kehittyä tarpeeksi (NisSINEN 1972). Keväällä lämminvetisen tulvan jälkeinen veden kylmeneminen on yleensä erittäin tuhoisa. Voimakkaat syysmyrskyt puolestaan saattavat tukahduttaa mädin jo syksyllä (SEPpovaArä 1969).

Muikun saalisarvot vaihtelevat eri vuosina seuraavasti: 19594891 tn (HeikKinen 1960); 19643557 tn, 19653685 tn (Hintikka 1967, 1969); 1967 4132 tn (Sutela 1968) ja 19695683 tn (Sutela 1970). Pääosa muikusta käytetään tuoreena. Vuoden 1966 saaliista (НıNтıккA 1969) 4580 tn käytettiin ihmis- ja 114 tn eläinravinnoksi. Jalostetun kalan osuus oli vain 293 tn.

Muikun syötävän osan keskimääräinen energiasisältö on $99 \mathrm{kcal} / 100 \mathrm{~g}$. Muikun vesipitoisuus on keskimäärin $78 \%$, valkuaisaineita on $18 \%$, rasvoja $2.5 \%$ ja tuhkaa $1.5 \%$. Sataa grammaa kohden on kalsiumia $20 \mathrm{mg}$, rautaa $0.6 \mathrm{mg}$, A-vitamiinia $30 \mathrm{ky}$, tiamiinia $0.07 \mathrm{mg}$, riboflaviinia $0.07 \mathrm{mg}$ sekä niasiinia $4.0 \mathrm{mg}$ (TURPEINEN ja RoINe 1967). Koska muikun lihaksen glykogeenipitoisuus on erittäin alhainen, rigor mortista ei varsinkaan lämpimässä ja nuotalla pyydetyssä muikussa tapahdu tai se tapahtuu hyvin äkkiä. Tämä rajoittaa muikun käyttömahdollisuuksia suuresti. Tuoreesta ja hyvänlaatuisesta muikusta on muuten mahdollista valmistaa esim. hyvälaatuisia täyssäilykkeitä (NIKKILÄ ym. 1971).

Tämän työn tarkoituksena oli tutkia kolmesta eri järvestä, Keiteleestä, Konnevedestä ja Niinivedestä pyydetyn muikun tuoresäilyvyyttä eri kuukausina. Tarkoituksena oli selvittää, kuinka nopeasti kala on saatava joko kuluttajalle tai jalostukseen. Toisena asiana pyrittiin selvittämään nuottamuikun kokojakautumaa ja perkaushukkaa.

\section{Materiaali ja menetelmät}

P y y n t i: Pyynti suoritettiin nuotalla Keiteleestä, Konnevedestä ja Niinivedestä. $10-20 \mathrm{~kg}: n$ tutkimuserät käsiteltiin pyyntiyötä seuraavana aamuna.

$\mathrm{K}$ a lojen käsittely: Puolet muikuista perattiin poistamalla käsin pää ja suoli. Sen jälkeen peratut kalat huuhdeltiin nopeasti jäävedessä. Peratut ja perkaamattomat kalat jaettiin kahteen osaan, joita säilytettiin ilman säilöntäaineita $+4^{\circ} \mathrm{C}$ :ssa ja $+10^{\circ} \mathrm{C}$ :ssa. Näytteet otettiin $1,2,3,5$ ja 7 vrk:n kuluttua.

Mikrobiologiset mä äritykset: Psykrofiilisten ja mesofiilisten bakteerien määritys sekä kokonaiskoliformipitoisuuden määritys suoritettiin Gyllenbergin ym. (1966) mukaan.

Rasvan elta antuminen: Rasvan eltaantumisen kriteeriksi valittiin TBA-luku, koska sen avulla oli saatu lupaavia tuloksia pakastetun silakan rasvan eltaantumista koskevissa tutkimuksissa. TBA-luku määritettiin Yu'n ja Sinnhuberin (1957) mukaan.

p H : n mä ärit y s: Kalat jauhettiin Ultra-Turrax homogenisaattorilla (JANke \& Kunkel KG, TP 18/2, 20000 r/min.) löysäksi massaksi, josta pH mitattiin. 
$\mathrm{K}$ o k o j a k a u t u a: Muikut jaoteltiin ennen perkausta kolmeen koko luokkaan seuraavasti:

$\begin{array}{llr}\text { isot muikut } & \text { yli } & 16 \mathrm{~g} \\ \text { keskikokoiset muikut } & 10-16 \mathrm{~g} \\ \text { pienet muikut } & \text { alle } 10 \mathrm{~g}\end{array}$

P e r k a u s a p p i o: Huuhtomisen jälkeen peratut kalat punnittiin.

Perkaushukka $\%=100-\frac{100 \times \text { perattujen kalojen paino }}{\text { perkaamattomien kalojen paino }}$

\section{Tulokset ja tulosten tarkastelu}

M i krobiologiset määritykset

Näytteistä saadut bakteerimäärät on esitetty kuvina 1-9, joissa kasvukäyrät pääpiirteissään noudattavat normaalia bakteerien kasvukäyrän muotoa.

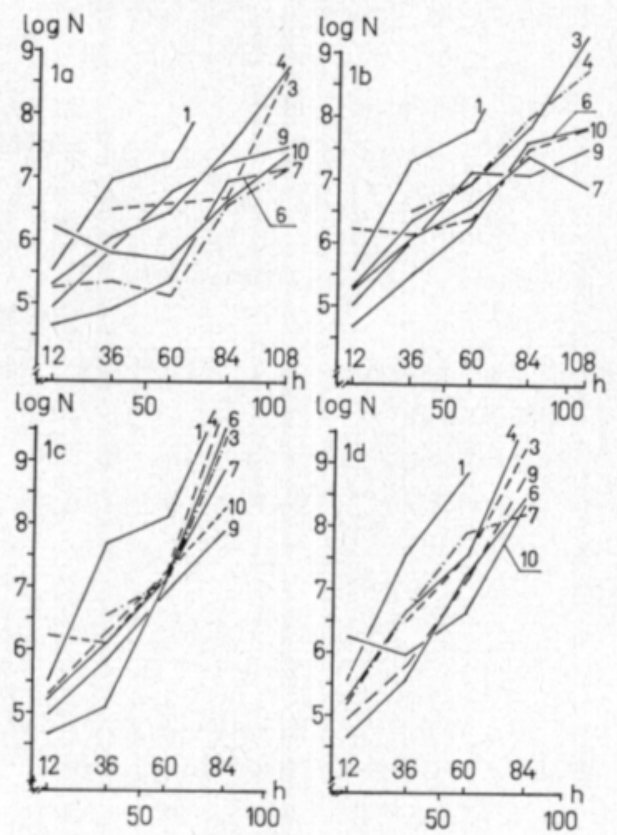

Kuvat 1 a-d. Keiteleestä pyydetyn muikun psykrofiiliset bakteerit.

Bakteerien lukumäärien logaritmit ajan funktiona ( $\mathrm{h}=$ tuntia). Käyrät on numeroitu pyyntikuukauden mukaan.
a. perattu $+4^{\circ} \mathrm{C}$ :ssa
b. perkaamaton $+4^{\circ} \mathrm{C}$ :ssa
c. perattu $+10^{\circ} \mathrm{C}$ :ssa
d. perkaamaton $+10^{\circ} \mathrm{C}$ :ssa

Figures 1 a-d. Psycrophilic bacteria of muikku (Coregonus albula L.) fished from the lake of Keitele.

Logarithms of the numbers of bacteria as a function of time ( $h=$ hours). The curves are numbered according to the fishing month.
a. gutted at $+4^{\circ} \mathrm{C}$
b. not gutted at $+4^{\circ} \mathrm{C}$
c. gutted at $+10^{\circ} \mathrm{C}$
d. not gutted at $+10^{\circ} \mathrm{C}$

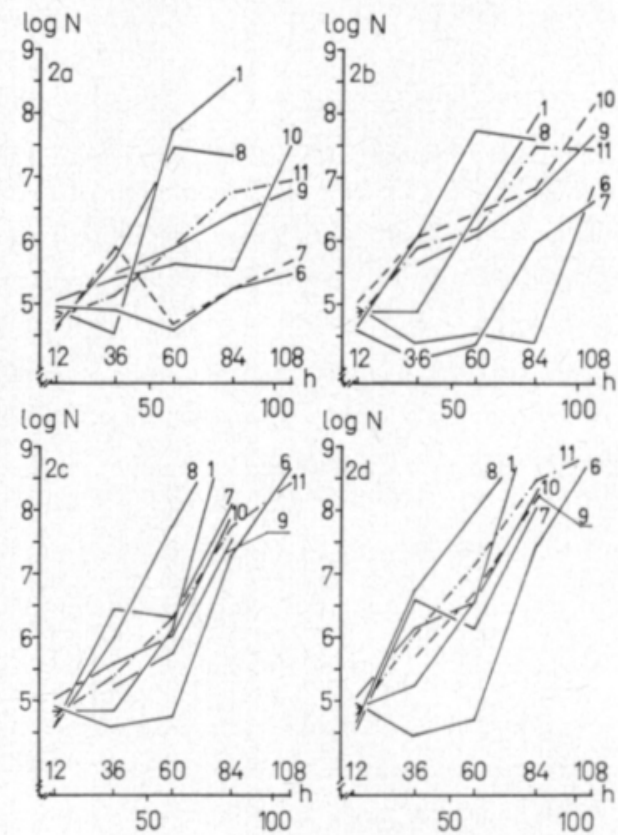

Kuvat 2 a-d. Konnevedestä pyydetyn muikun psykrofiiliset bakteerit. Tunnukset kuten kuvassa 1.

Figures 2 a-d. Psycrophilic bacteria of muikku (Coregonus albula L.) fished from the lake of Konnevesi. Symbols as in Fig. 1. 




\section{$\log N$}

$\left.{ }^{9}\right]^{3 b}$
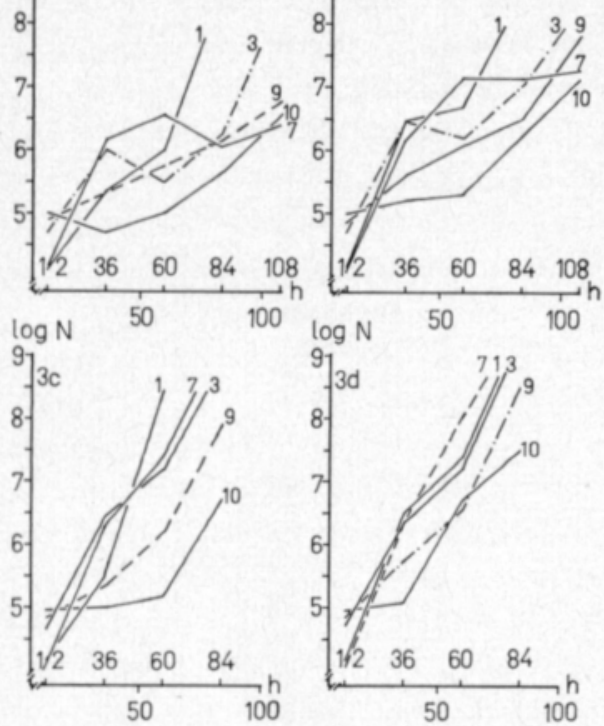

$\log N \quad 50 \quad 100$

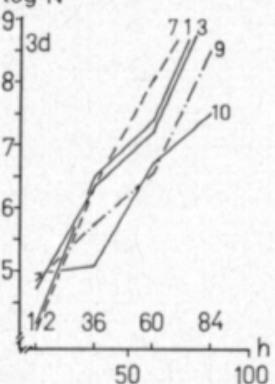

Kuvat 3 a-d. Niinivedestä pyydetyn muikun psykrofiiliset bakteerit. Tunnukset kuten kuvassa 1.

Figures $3 a-d$. Psycrophilic bacteria of muikku (Coregonus albula L.) fished from the lake of Niinivesi. Symbols as in Fig. 1.
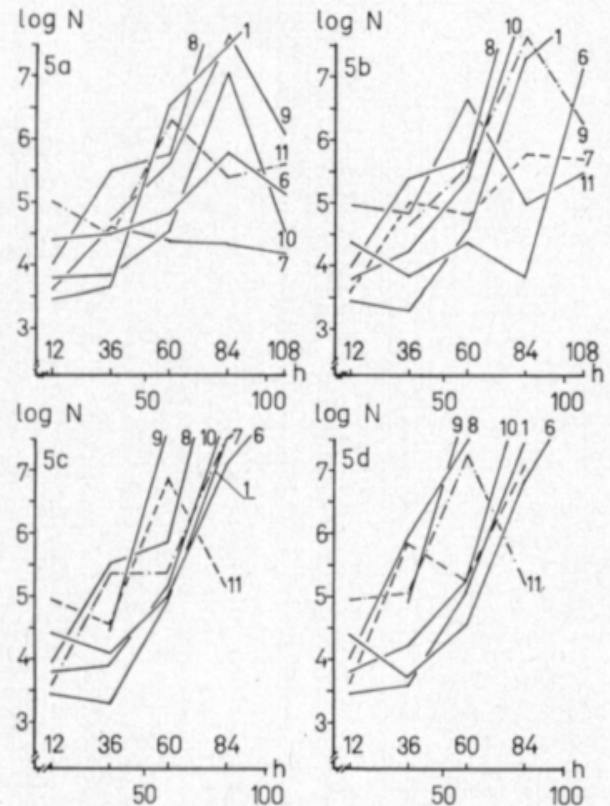

Kuvat 5 a-d. Konnevedestä pyydetyn muikun mesofiiliset bakteerit. Tunnukset kuten kuvassa 1.

Figures $5 a-d$. Mesophilic bacteria of muikku (Coregonus albula L.) fished from the lake of Konnevesi. Symbols as in Fig. 1.
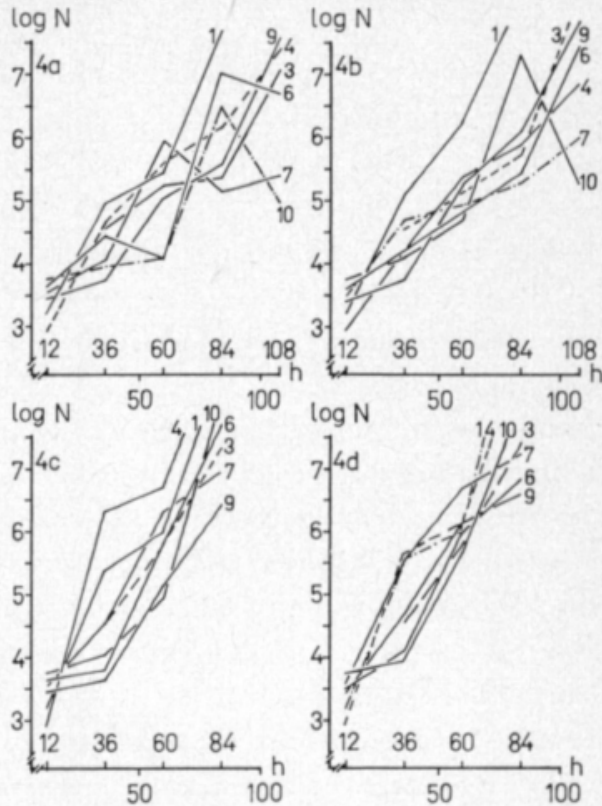

Kuvat 4 a-d. Keiteleestä pyydetyn muikun mesofiiliset bakteerit. Tunnukset kuten kuvassa 1.

Figures $4 a-d$. Mesophilic bacteria of muikku (Coregonus albula L.) fished from the lake of Keitele. Symbols as in Fig. 1.
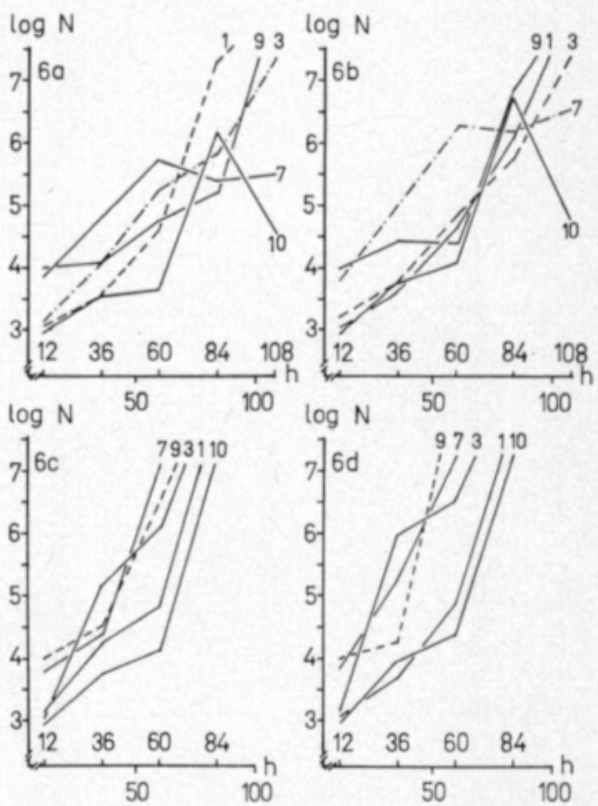

Kuvat 6 a-d. Niinivedestä pyydetyn muikun mesofiiliset bakteerit. Tunnukset kuten kuvassa 1.

Figures $6 a-d$. Mesophilic bacteria of muikku (Coregonus albula L) fished from the lake of Niinivesi. Symbols as in Fig. 1. 
Perattuina ja perkaamattomina säilytettyjen muikkujen bakteerimäärissä ei ollut huomattavia eroja. Tämän perusteella käsin perkausta ei voida suositella muikkujen perkaustavaksi. Bakteerimäärät eri vesistä kalastetuissa muikuissa vaihtelivat sangen vähän (kuvat 1-9). Saman kuukauden näytteet olivat aina yhdenvertaiset kaikissa kolmessa järvessä.

Psykrofiilisten bakteerien määrä oli mesofiilisten määrää suurempi johtuen ilmeisesti pyyntivesien mesofiilisten bakteerien kasvulle liian alhaisesta lämpötilasta.

Koliformibakteerien kasvu rajoittui pääasiassa kesäkuukausiin (kesäelokuu), jolloin vesien lämpötila oli korkeimmillaan.

Säilyvyyden kriteerinä on käytetty FAO:n suositusta (SHEwAN 1970), missä suurin sallittu kokonaisbakteerimäärä varastoidun kalan pintalimassa on $10^{4-5} \mathrm{kpl} / \mathrm{g}$ ja lihasnesteessä $10^{3} \mathrm{kpl} / \mathrm{g}$. Kauppakuntoisuusrajana tässä tutkimuksessa pidettiin kokonaisbakteerimäärää $5 \times 10^{4} \mathrm{kpl} / \mathrm{g}$, jolloin muikut säilyivät kauppakuntoisina $+4^{\circ} \mathrm{C}$ :ssa $24-36$ tuntia ja $+10^{\circ} \mathrm{C}$ :ssa alle 24 tuntia. Kesä- ja talvikuukausina ei ollut huomattavaa eroa säilyvyydessä, mikä osoittaa kalan alkuperäisen mikrobiston samankaltaisuutta.
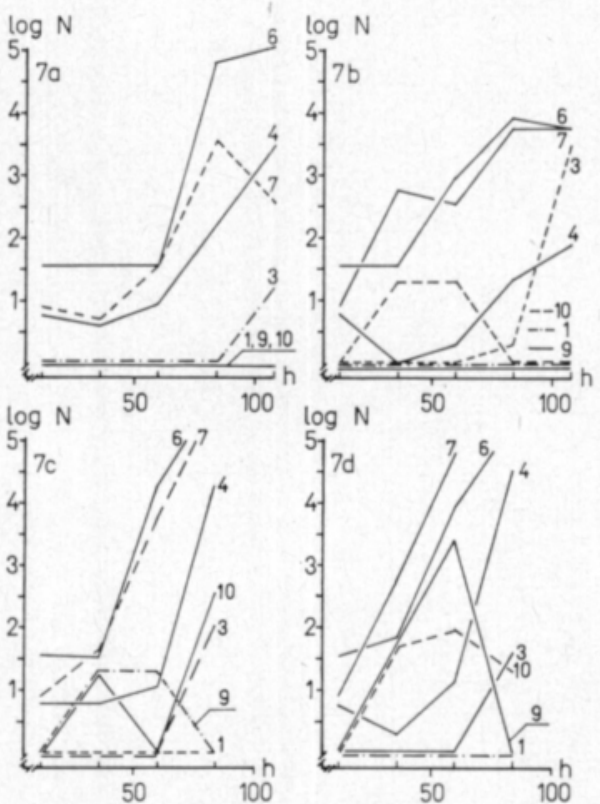

Kuvat 7 a-d. Keiteleestä pyydetyn muikun koliformibakteerit. Tunnukset kuten kuvassa 1 .

Figures $7 a-d$. Coliform bacteria of muikku (Coregonus albula L.) fished from the lake of Keitele. Symbols as in Fig. 1.
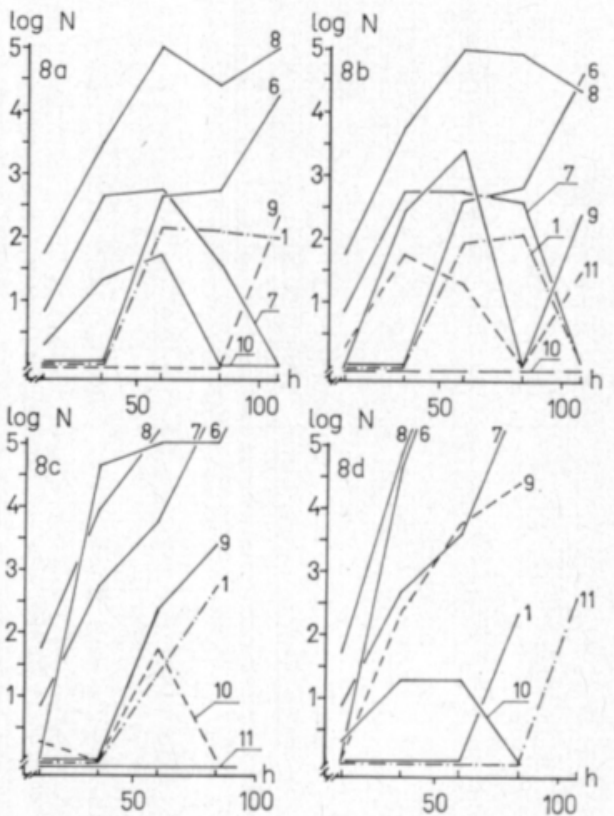

Kuvat 8 a-d. Konnevedestä pyydetyn muikun koliformibakteerit. Tunnukset kuten kuvassa 1.

Figures 8 a-d. Coliform bacteria of muikku (Coregonus albula L.) fished from the lake of Konnevesi. Symbols as in Fif. 1. 

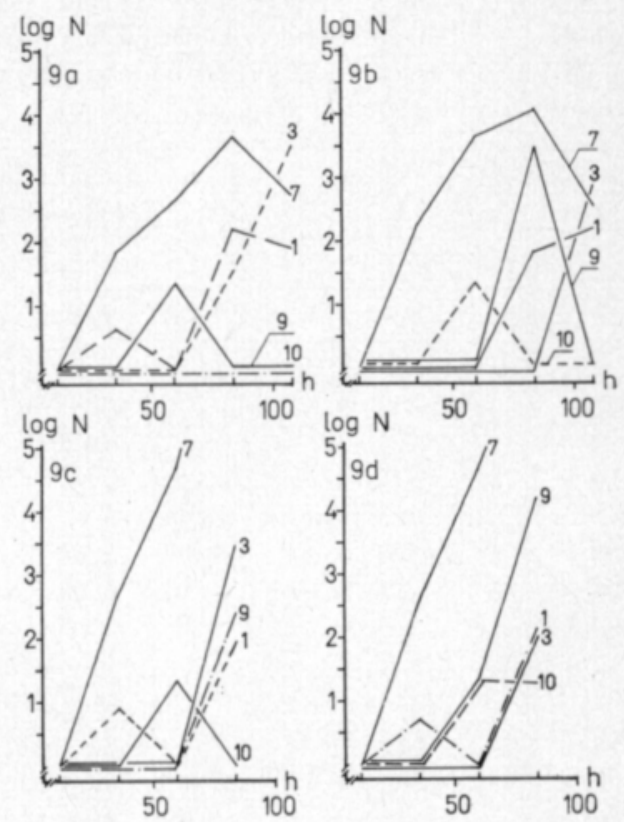

Kuvat 9 a-d. Niinivedestä pyydetyn muikun koliformibakteerit. Tunnukset kuten kuvassa 1.

Figures $9 a-d$. Coliform bacteria of muikku (Coregonus albula L.) fished from the lake of Ninivesi. Symbols as in Fig. 1.

Rasvan eltaantuminen ja pH

TBA-luvulla oli tarkoitus seurata kemiallisesti muikun rasvan eltaantumista. Kuten taulukoista $1-3$ nähdään, TBA-luvulla ei saatu mitään kuvaa pilaantumisen edistymisestä. Ilmeisesti kalassa tapahtuvat muut muutokset kuten entsymaattinen pilaantuminen tapahtuivat nopeammin kuin rasvan eltaantuminen.

pH määrityksen avulla pyrittiin saamaan yleiskuva happamuusasteessa tapahtuvista muutoksista muikussa säilytyksen aikana. Taulukosta 4 nähdään, että lähtökohdan pH oli sitä korkeampi mitä alhaisempi oli pyyntiveden lämpötila. Pyyntivesien ollessa jäässä muikku jäätyi heti vedestä nostamisen jälkeen. Tällöin muikun pH-arvot olivat lähellä 7. Nämä olivat samaa suuruusluokkaa MesstoRfFin (1954 a) saamien arvojen kanssa, mitkä oli mitattu merikaloista tunti pyynnin jälkeen. pH laski 7:stä ensimmäisinä vasrastointivuorokausina noustakseen sen jälkeen (kuvat 10-12).

Teurastuksen jälkeisiä $\mathrm{pH}: \mathrm{n}$ muutoksia on tutkinut mm. MesstorfF (1954 b). Hänen mukaansa teurastuksen jälkeen kalan $\mathrm{pH}$ laskee rigor mortiksen alkaessa ja kestäessä. Tämän vaiheen jälkeen $\mathrm{pH}$ jälleen kohoaa. Tutkimus osoitti lisäksi, että kalan jäädyttyä heti vedestä nostamisen jälkeen rigor mortis-vaihe pysähtyi tai oli voimakkaasti hidastunut sulatukseen saakka. 
Taulukko 1. Keiteleestä eri kuukausina pyydetyn muikun TBA-luku ja pH

Table 1. TBA-value and $p H$ of muikku (Coregon us albula L.) fished during various months from the lake of Keitele

\begin{tabular}{|c|c|c|c|c|c|c|c|c|c|c|c|}
\hline \multirow{3}{*}{\multicolumn{2}{|c|}{$\begin{array}{l}\text { Kuukausi } \\
\text { Month }\end{array}$}} & \multicolumn{8}{|c|}{$\begin{array}{l}\text { Säilytysaika, tuntia } \\
\text { Taim of storing, hours }\end{array}$} & & \\
\hline & & \multicolumn{2}{|c|}{12} & \multicolumn{2}{|c|}{36} & \multicolumn{2}{|c|}{60} & \multicolumn{2}{|c|}{84} & \multicolumn{2}{|c|}{108} \\
\hline & & TBA & $\mathrm{pH}$ & TBA & $\mathrm{pH}$ & TBA & $\mathrm{pH}$ & TBA & $\mathrm{pH}$ & TBA & $\mathrm{pH}$ \\
\hline \multicolumn{12}{|c|}{$\begin{array}{l}\text { perattu }+4^{\circ} \mathrm{C}: \mathrm{ssa} \\
\text { gutted at }+4^{\circ} \mathrm{C}\end{array}$} \\
\hline 6 & ............... & 10.8 & 6.72 & 11.0 & 6.81 & 7.9 & 6.80 & 5.9 & 6.89 & 3.2 & 6.90 \\
\hline 7 & .............. & 14.5 & 6.19 & 5.6 & 6.51 & 4.2 & 6.54 & 9.8 & 6.54 & 8.1 & 6.48 \\
\hline 9 & .............. & 0.3 & 6.42 & 0.6 & 6.51 & 1.1 & 6.54 & 1.8 & 6.53 & 1.8 & 6.51 \\
\hline 10 & …........... & 2.1 & 6.90 & 1.7 & 6.95 & 2.0 & 6.89 & 1.6 & 6.89 & 1.4 & 6.77 \\
\hline \multicolumn{12}{|c|}{$\begin{array}{c}\text { perkaamaton }+4^{\circ} \mathrm{C} \text { :ssa } \\
\text { not gutted at }+4^{\circ} \mathrm{C}\end{array}$} \\
\hline 6 & ............... & 10.8 & 6.72 & 17.6 & 6.80 & 13.2 & 6.80 & 9.0 & 6.41 & 4.3 & 6.82 \\
\hline 7 & ............... & 14.5 & 6.19 & 5.4 & 6.60 & 5.0 & 6.58 & 2.5 & 6.61 & 2.2 & 6.48 \\
\hline 9 & .............. & 0.3 & 6.42 & 0.4 & 6.42 & 1.2 & 6.51 & 3.3 & 6.59 & 2.4 & 6.51 \\
\hline 10 & ............... & 2.1 & 6.90 & 2.0 & 6.80 & 2.2 & 6.83 & 1.9 & 6.81 & 1.8 & 6.80 \\
\hline \multicolumn{12}{|c|}{$\begin{array}{l}\text { perattu }+10^{\circ} \mathrm{C}: \mathrm{ssa} \\
\text { gutted at }+10^{\circ} \mathrm{C}\end{array}$} \\
\hline 6 & n.w. & 10.8 & 6.72 & 13.2 & 6.80 & 9.7 & 6.86 & 6.7 & 6.92 & 5.0 & 7.13 \\
\hline 7 & .............. & 14.5 & 6.19 & 2.9 & 6.54 & 6.4 & 6.49 & 19.5 & 6.88 & - & - \\
\hline 9 & ............. & 0.3 & 6.42 & 0.6 & 6.42 & 0.4 & 6.51 & 1.8 & 6.62 & - & - \\
\hline 10 & ............... & 2.1 & 6.90 & 2.2 & 6.82 & 1.7 & 6.85 & 1.8 & 6.81 & - & - \\
\hline \multicolumn{12}{|c|}{$\begin{array}{c}\text { perkaamaton }+10^{\circ} \mathrm{C} \text { :ssa } \\
\text { not gutted at }+10^{\circ} \mathrm{C}\end{array}$} \\
\hline 6 & ............... & 10.8 & 6.72 & 7.4 & 6.82 & 9.6 & 6.92 & 6.1 & 7.07 & 9.9 & 7.31 \\
\hline 7 & ............... & 14.5 & 6.19 & 6.0 & 6.49 & 11.9 & 6.59 & 18.1 & 7.00 & - & - \\
\hline 9 & .............. & 0.3 & 6.42 & 1.3 & 6.44 & 1.9 & 6.54 & 1.0 & 6.50 & - & - \\
\hline 10 & ............... & 2.1 & 6.90 & 1.9 & 6.88 & 1.6 & 6.87 & 1.8 & 6.78 & - & - \\
\hline
\end{tabular}


Taulukko 2. Konnevedestä eri kuukausina pyydetyn muikun TBA-luku ja pH.

Table 2. TBA-value and $p H$ of muikku (Coregonus albula L.) fished during various months from the lake of Konnevesi.

\begin{tabular}{|c|c|c|c|c|c|c|c|c|c|c|c|}
\hline \multirow{3}{*}{\multicolumn{2}{|c|}{$\begin{array}{l}\text { Kuukausi } \\
\text { Month }\end{array}$}} & \multicolumn{10}{|c|}{$\begin{array}{l}\text { Säilytysaika, tuntia } \\
\text { Time of storing, hours }\end{array}$} \\
\hline & & \multicolumn{2}{|c|}{12} & \multicolumn{2}{|c|}{36} & \multicolumn{2}{|c|}{60} & \multicolumn{2}{|c|}{84} & \multicolumn{2}{|c|}{108} \\
\hline & & TBA & $\mathrm{pH}$ & TBA & $\mathrm{pH}$ & TBA & $\mathrm{pH}$ & TBA & $\mathrm{pH}$ & TBA & $\mathrm{pH}$ \\
\hline \multicolumn{12}{|c|}{$\begin{array}{l}\text { perattu }+4^{\circ} \mathrm{C}: \text { ssa } \\
\text { gutted at }+4^{\circ} \mathrm{C}\end{array}$} \\
\hline 6 & …........... & 9.0 & 6.70 & 9.8 & 6.57 & 8.0 & 6.67 & 3.5 & 6.79 & 4.4 & 6.79 \\
\hline 7 & ……....... & 11.6 & 6.21 & 8.5 & 6.58 & 8.7 & 6.30 & 7.5 & 6.30 & 9.0 & 6.32 \\
\hline 8 & .............. & 1.4 & 6.38 & 1.6 & 6.32 & 3.4 & 6.32 & 3.2 & 6.31 & 4.2 & 6.70 \\
\hline 9 & ............... & 1.9 & 6.77 & 2.7 & 6.80 & 2.7 & 6.82 & 1.4 & 6.61 & 2.6 & 6.49 \\
\hline 10 & ................ & 1.6 & 6.58 & 2.0 & 6.21 & 1.4 & 6.17 & 3.1 & 6.23 & 1.4 & 6.29 \\
\hline 11 & .............. & 2.0 & 6.59 & 2.4 & 6.65 & 2.7 & 6.73 & 2.0 & 6.75 & 4.1 & 6.78 \\
\hline \multicolumn{12}{|c|}{$\begin{array}{c}\text { perkaamaton }+4^{\circ} \mathrm{C} \text { :ssa } \\
\text { not gutted at }+4^{\circ} \mathrm{C}\end{array}$} \\
\hline 6 & ............... & 9.0 & 6.70 & 9.5 & 6.60 & 6.2 & 6.79 & 4.2 & 6.78 & 5.0 & 6.82 \\
\hline 7 & .............. & 11.6 & 6.21 & 12.5 & 6.61 & 10.7 & 6.31 & 9.4 & 6.36 & 14.9 & 6.39 \\
\hline 8 & .............. & 1.4 & 6.38 & 2.5 & 6.32 & 4.6 & 6.33 & 5.4 & 6.46 & 6.3 & 6.62 \\
\hline 9 & .............. & 1.9 & 6.77 & 5.5 & 6.83 & 2.1 & 6.47 & 1.3 & 6.55 & 5.9 & 6.50 \\
\hline 10 & .............. & 1.6 & 6.58 & 1.9 & 6.17 & 1.5 & 6.22 & 1.6 & 6.20 & 1.4 & 6.24 \\
\hline 11 & ............... & 2.0 & 6.59 & 2.1 & 6.73 & 1.9 & 6.71 & 2.3 & 6.73 & 2.8 & 6.79 \\
\hline \multicolumn{12}{|c|}{$\begin{array}{l}\text { perattu }+10^{\circ} \mathrm{C}: \mathrm{ssa} \\
\text { gutted at }+10^{\circ} \mathrm{C}\end{array}$} \\
\hline 6 & ............... & 9.0 & 6.70 & 10.5 & 6.50 & 3.7 & 6.85 & 4.3 & 6.78 & 5.6 & 7.10 \\
\hline 7 & .............. & 11.6 & 6.21 & 9.3 & 6.28 & 2.7 & 6.29 & 5.6 & 6.48 & - & - \\
\hline 8 & .............. & 1.4 & 6.38 & 3.5 & 6.31 & 2.5 & 6.32 & 2.0 & 6.58 & - & - \\
\hline 9 & .............. & 1.9 & 6.77 & 3.3 & 6.82 & 1.4 & 6.58 & 2.0 & 6.69 & - & - \\
\hline 10 & .............. & 1.6 & 6.58 & 3.1 & 6.19 & 1.2 & 6.20 & 2.7 & 6.28 & - & - \\
\hline 11 & ............... & 2.0 & 6.59 & 2.3 & 6.70 & 1.6 & 6.75 & 2.5 & 6.70 & 3.6 & 6.80 \\
\hline \multicolumn{12}{|c|}{$\begin{array}{c}\text { perkaamaton }+10^{\circ} \mathrm{C} \text { :ssa } \\
\text { not gutted at }+10^{\circ} \mathrm{C}\end{array}$} \\
\hline 6 & .............. & 9.0 & 6.70 & 10.7 & 6.50 & 4.2 & 6.80 & 6.0 & 6.90 & 6.3 & 7.31 \\
\hline 7 & ............... & 11.6 & 6.21 & 3.7 & 6.31 & 5.7 & 6.30 & 13.7 & 6.43 & - & - \\
\hline 8 & n............. & 1.4 & 6.38 & 4.9 & 6.29 & 4.7 & 6.29 & 4.0 & 6.90 & - & - \\
\hline 9 & .............. & 1.9 & 6.77 & 2.5 & 6.72 & 3.0 & 6.53 & 4.9 & 6.49 & - & - \\
\hline 10 & .............. & 1.6 & 6.58 & 3.1 & 6.18 & 2.8 & 6.21 & 3.7 & 6.31 & - & - \\
\hline 11 & n.t.c........ & 2.0 & 6.59 & 1.9 & 6.70 & 2.5 & 6.71 & 4.2 & 6.72 & 2.6 & 6.99 \\
\hline
\end{tabular}


Taulukko 3. Niinivedestä eri kuukausina pyydetyn muikun TBA-luku ja pH.

Table 3. TBA-value and $p H$ of muikku (Coregonus albula L.) fished during various months from the lake of Niinivesi.

\begin{tabular}{|c|c|c|c|c|c|c|c|c|c|c|c|}
\hline \multirow{3}{*}{\multicolumn{2}{|c|}{$\begin{array}{l}\text { Kuukausi } \\
\text { Month }\end{array}$}} & \multicolumn{10}{|c|}{$\begin{array}{l}\text { Säilytysaika, tuntia } \\
\text { Time of storing, hours }\end{array}$} \\
\hline & & \multicolumn{2}{|c|}{12} & \multicolumn{2}{|c|}{36} & \multicolumn{2}{|c|}{60} & \multicolumn{2}{|c|}{84} & \multicolumn{2}{|c|}{108} \\
\hline & & TBA & $\mathrm{pH}$ & TBA & $\mathrm{pH}$ & TBA & $\mathrm{pH}$ & TBA & $\mathrm{pH}$ & TBA & $\mathrm{pH}$ \\
\hline \multicolumn{12}{|c|}{$\begin{array}{l}\text { perattu }+4^{\circ} \text { Cssa } \\
\text { gutted at }+4^{\circ} \mathrm{C}\end{array}$} \\
\hline 7 & n............. & 16.9 & 6.22 & 7.7 & 6.51 & 7.0 & 6.42 & 10.3 & 6.59 & 9.0 & 6.58 \\
\hline 9 & ............... & 1.6 & 6.46 & 3.0 & 6.49 & 6.8 & 6.42 & 2.9 & 6.48 & 1.6 & 6.51 \\
\hline 10 & n.............. & 1.3 & 6.17 & 1.6 & 6.26 & 1.5 & 6.31 & 2.1 & 6.69 & 1.8 & 6.70 \\
\hline \multicolumn{12}{|c|}{$\begin{array}{c}\text { perkaamaton }+4^{\circ} \mathrm{C}: \mathrm{ssa} \\
\text { not gutted at }+4^{\circ} \mathrm{C}\end{array}$} \\
\hline 7 & .............. & 16.9 & 6.22 & 10.2 & 6.41 & 9.8 & 6.48 & 15.0 & 6.59 & 1.8 & 6.61 \\
\hline 9 & ............... & 1.6 & 6.46 & 2.3 & 6.45 & 2.8 & 6.51 & 6.2 & 6.50 & 9.4 & 6.49 \\
\hline 10 & & 1.3 & 6.17 & 1.5 & 6.27 & 1.4 & 6.30 & 1.8 & 6.75 & 1.6 & 6.74 \\
\hline \multicolumn{12}{|c|}{$\begin{array}{c}\text { perattu }+10^{\circ} \mathrm{C}: \mathrm{ssa} \\
\text { gutted at }+10^{\circ} \mathrm{C}\end{array}$} \\
\hline 7 & ............... & 16.9 & 6.22 & 5.8 & 6.43 & 8.4 & 6.47 & 7.8 & 6.79 & - & - \\
\hline 9 & ............... & 1.6 & 6.46 & 0.6 & 6.38 & 2.9 & 6.49 & 3.8 & 6.60 & - & - \\
\hline 10 & ............... & 1.3 & 6.17 & 1.5 & 6.34 & 1.4 & 6.28 & 1.8 & 6.73 & - & - \\
\hline \multicolumn{12}{|c|}{$\begin{array}{c}\text { perkaamaton }+10^{\circ} \mathrm{Cssa} \\
\text { not gutted at }+10^{\circ} \mathrm{C}\end{array}$} \\
\hline 7 & .............. & 16.9 & 6.22 & 6.1 & 6.40 & 12.5 & 6.57 & 11.9 & 6.92 & - & - \\
\hline 9 & ............... & 1.6 & 6.46 & 1.2 & 6.47 & 1.1 & 6.55 & 1.2 & 6.67 & - & - \\
\hline 10 & .............. & 1.3 & 6.17 & 1.6 & 6.30 & 1.4 & 6.31 & 1.7 & 6.79 & - & - \\
\hline
\end{tabular}

Taulukko 4. Pyyntiveden lämpötila sekä Keiteleestä, Konnevedestä ja Niinivedestä nuotalla pyydetyn muikun $\mathrm{pH}$ eri kuukausina.

Table 4. Temperature of fishing water and pH of muikku (Coregonus albula L.) fished with seine from the lakes of Keitele, Konnevesi, and Niinivesi during various months.

\begin{tabular}{|c|c|c|c|c|}
\hline \multirow{2}{*}{$\begin{array}{l}\text { Kuukausi } \\
\text { Month }\end{array}$} & \multirow{2}{*}{$\begin{array}{c}\text { Pyyntiveden } \\
\text { lämpötila }{ }^{\circ} \mathrm{C} \\
\text { Temperature } \\
\text { of fishing } \\
\text { water }{ }^{\circ} \mathrm{C}\end{array}$} & \multicolumn{3}{|c|}{$\mathrm{pH}$} \\
\hline & & Keitele & Konnevesi & Niinivesi \\
\hline 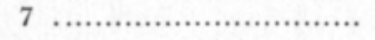 & 18 & 6.02 & 6.28 & 6.10 \\
\hline 8 .............................. & 17 & - & 6.28 & - \\
\hline 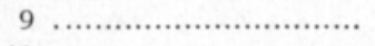 & 10 & 6.18 & 6.38 & 6.40 \\
\hline 10 ........................... & 3 & 6.67 & 6.50 & 6.61 \\
\hline 11 (n............................ & 0.3 & - & 6.82 & - \\
\hline 1 ( & 0.3 & 7.00 & - & - \\
\hline 4 .............................. & 0.3 & 7.10 & - & - \\
\hline
\end{tabular}




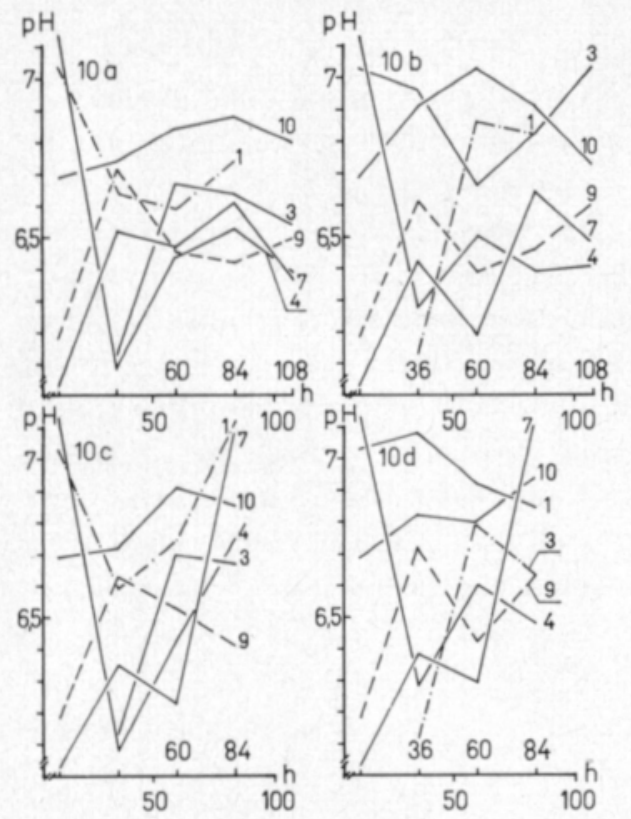

Kuvat 10 a-d. Keiteleestä pyydetty muikku.

$\mathrm{pH}$ ajan funktiona ( $\mathrm{h}=$ tuntia). Käyrät on numeroitu pyyntikuukauden mukaan

a. perattu $+4^{\circ} \mathrm{C}$ :ssa

b. perkaamaton $+4^{\circ} \mathrm{C}$ :ssa

c. perattu $+10^{\circ} \mathrm{C}: \mathrm{ssa}$

d. perkaamaton $+10^{\circ} \mathrm{C}$ :ssa

Fig 10 a-d. Muikku (Coregonus a $l b u l a L$.) fished from the lake of Keitele. $p H$ as a function of time ( $h=$ hours). The curves are numbered according to the fishing month
a. gutted at $+4^{\circ} \mathrm{C}$
b. not gutted at $+4^{\circ} \mathrm{C}$
c. gutted at $+10^{\circ} \mathrm{C}$
d. not gutted at $+10^{\circ} \mathrm{C}$


Kuvat 11 a-d. Konnevedestä pyydetty muikku. Tunnukset kuten kuvassa 10.

Figures 11 a-d. Muikku (Coregonus a l b ula L.) fished from the lake of Konnevesi. Symbols as in Fig. 10.
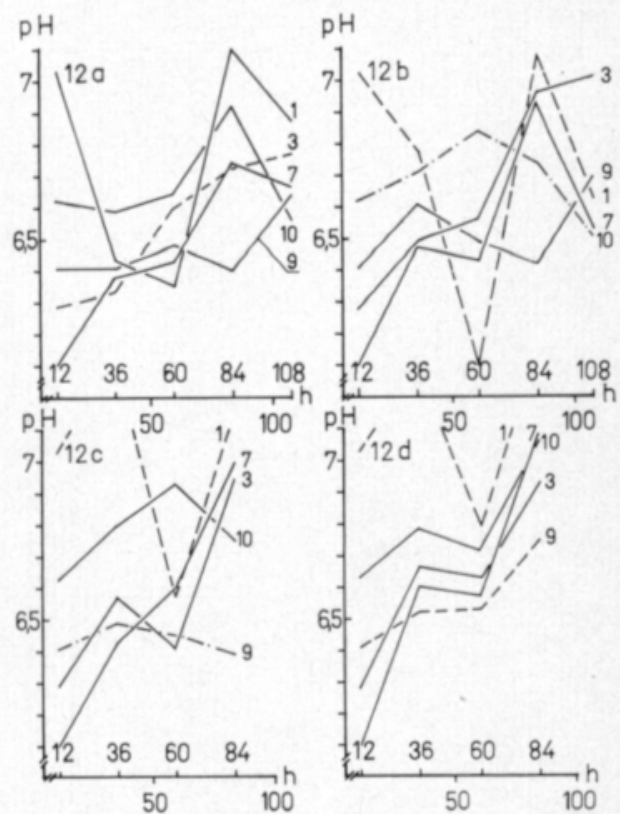

Kuvat 12 a-d. Niinivedestä pyydetty muikku. Tunnukset kuten kuvassa 10.

Figures 12 a-d. Muikku (Coregonus a l b ula L.) fished from the lake of Niinivesi. Symbols as in Fig. 10. 
Ko k oja k a u u m a

Kuten taulukosta 5 ilmenee, oli nuotalla pyydetyn muikun kokojakautuman huippu keskikokoisten (10-16 g) kohdalla. Muutamia poikkeuksia lukuunottamatta tuli näiden osuudeksi yli $60 \%$ saalista kaikissa kolmessa tutkimuskohteessa. Näiden kolmen järven keskimääräisessä kokojakautumassa oli isojen osuus $13.5 \%$, keskikokoisten $65.4 \%$ ja pienten $21.1 \%$. Konnevedestä, mistä havaintoja oli eniten, havaitaan syyskuussa saadun poikkeuksellisen suuri määrä isoja muikkuja ja lokakuussa taasen pieniä. Tähän lienee syynä muikun liikehdintä, josta JäRvI (1919) on todennut, että muikku liikkuu vain syvänteistä mataliin vesiin syömään, takaisin syvänteisiin ja taasen mataliin vesiin, missä kutu tapahtuu. Kutuun ottavat osaa muut paitsi ensimmäisen vuoden muikut. Tältä pohjalta voitaisiin otaksua, että lokakuussa näytteeksi saadut muikut oli pyydetty isojen ollessa kudulla.

Taulukko 5. Keiteleestä, Konnevedestä ja Niinivedestä nuotalla pyydetyn muikun kokojakautuma eri kuukausina.

Table 5. Distribution of size of muikku (Coregonus albula L.) fished with seine from the lakes of Keitele, Konnevesi, avd Niinivesi during various months.

\begin{tabular}{|c|c|c|c|c|}
\hline \multirow{2}{*}{\multicolumn{2}{|c|}{$\begin{array}{l}\text { Kuukausi } \\
\text { Month }\end{array}$}} & \multicolumn{3}{|c|}{$\%$ saalista $-\%$ of the catch } \\
\hline & & $\begin{array}{l}\text { Isot } \\
\text { Big }\end{array}$ & $\begin{array}{c}\text { Keskikokoiset } \\
\text { Middle-sized }\end{array}$ & $\begin{array}{l}\text { Pienet } \\
\text { Small }\end{array}$ \\
\hline \multicolumn{5}{|c|}{ Keitele } \\
\hline 6 & (n................... & - & 74.0 & 26.0 \\
\hline 7 & (..................... & 8.5 & 80.5 & 10.9 \\
\hline 9 & (n.................... & 5.9 & 86.9 & 7.2 \\
\hline 1 & (n................... & 2.5 & 51.9 & 45.6 \\
\hline 3 & .......................... & 10.3 & 61.1 & 28.5 \\
\hline \multirow{3}{*}{\multicolumn{2}{|c|}{ 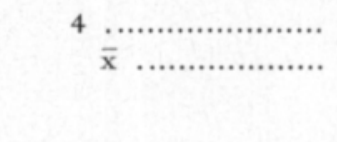 }} & 20.9 & 56.0 & 24.1 \\
\hline & & 8.0 & 68.4 & 23.6 \\
\hline & & \multicolumn{3}{|c|}{ Konnevesi } \\
\hline 6 & (n.................... & 10.2 & 73.6 & 16.2 \\
\hline 7 & (n.................... & 1.7 & 80.2 & 18.1 \\
\hline 8 & (...................... & 22.7 & 72.3 & 5.0 \\
\hline 9 & …................... & 36.3 & 49.0 & 14.7 \\
\hline 10 & (...................... & 12.8 & 23.5 & 63.7 \\
\hline 11 & ....................... & 6.2 & 64.4 & 29.4 \\
\hline \multirow[t]{3}{*}{1} & (n.................. & 3.9 & 56.4 & 39.7 \\
\hline & 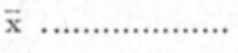 & 13.4 & 59.9 & 26.7 \\
\hline & \multicolumn{4}{|c|}{ Niinivesi } \\
\hline 7 & …................... & - & 74.1 & 25.9 \\
\hline 9 & (....................... & 10.7 & 66.5 & 22.8 \\
\hline 10 & 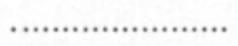 & 35.2 & 64.8 & - \\
\hline 1 & 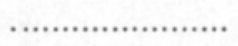 & 20.4 & 71.7 & 7.9 \\
\hline \multirow[t]{2}{*}{3} & ….................. & 29.4 & 63.0 & 7.6 \\
\hline & $\bar{x} \ldots \ldots \ldots \ldots \ldots \ldots$ & 19.1 & 68.0 & 12.9 \\
\hline \multicolumn{5}{|c|}{ Kaikkien keskiarvo } \\
\hline \multicolumn{2}{|c|}{ Average } & 13.5 & 65.4 & 21.1 \\
\hline
\end{tabular}


Taulukko 6. Keiteleestä, Konnevedestä ja Niinivedestä pyydetyn muikun perkaustappio eri kuukausina.

Table 6. Gutting waste of muikku (Coregonus albula L.) fished with seine from the lakes of Keitele, Konnevesi, and Niinivesi during various months.

\begin{tabular}{|c|c|c|c|c|}
\hline \multirow{2}{*}{$\begin{array}{l}\text { Kuukausi } \\
\text { Month }\end{array}$} & \multicolumn{4}{|c|}{ Perkaustappio $\%$ - Gutting waste $\%$} \\
\hline & \multirow{2}{*}{$\begin{array}{r}\text { Isot } \\
\text { Big }\end{array}$} & \multirow{2}{*}{$\begin{array}{c}\begin{array}{c}\text { Keskikokoiset } \\
\text { Middle-sized }\end{array} \\
\text { Keitele }\end{array}$} & \multirow{2}{*}{$\begin{array}{r}\text { Pienet } \\
\text { Small }\end{array}$} & \multirow{2}{*}{$\begin{array}{l}\text { koko saalis } \\
\text { Whole catch }\end{array}$} \\
\hline & & & & \\
\hline 6 & - & 25.3 & 26.1 & 25.5 \\
\hline 7 .................................. & 26.9 & 26.3 & 27.9 & 26.5 \\
\hline 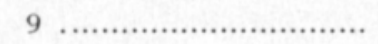 & 20.7 & 24.6 & 28.5 & 24.7 \\
\hline 1 & 27.1 & 25.5 & 27.5 & 26.5 \\
\hline 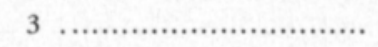 & 26.2 & 25.6 & 26.6 & 25.9 \\
\hline \multirow{3}{*}{4} & 22.8 & 25.1 & 24.9 & 24.8 \\
\hline & 24.7 & 25.4 & 26.9 & 25.6 \\
\hline & & Konnevesi & & \\
\hline 6 & 22.3 & 24.2 & 26.4 & 24.4 \\
\hline 7 & 26.3 & 24.6 & 27.1 & 25.1 \\
\hline 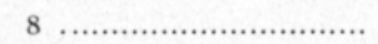 & 25.2 & 26.1 & 25.5 & 25.9 \\
\hline 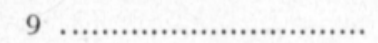 & 29.2 & 26.5 & 27.9 & 27.7 \\
\hline 10 …........................... & 25.3 & 26.9 & 27.0 & 26.8 \\
\hline 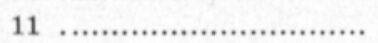 & 23.5 & 24.5 & 26.5 & 25.0 \\
\hline \multirow{3}{*}{1} & 27.3 & 27.2 & 26.5 & 26.9 \\
\hline & 25.6 & 25.7 & 26.3 & 25.9 \\
\hline & & Niinivesi & & \\
\hline 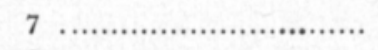 & - & 24.9 & 25.0 & 24.9 \\
\hline 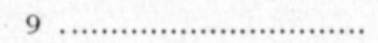 & 32.3 & 25.4 & 25.2 & 26.1 \\
\hline 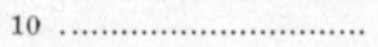 & 24.2 & 26.8 & & 25.9 \\
\hline 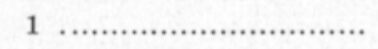 & 26.3 & 26.9 & 27.9 & 26.9 \\
\hline 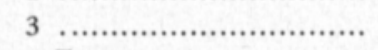 & 25.4 & 25.1 & 26.2 & 25.3 \\
\hline$\overline{\mathbf{x}} \ldots \ldots \ldots \ldots \ldots \ldots \ldots \ldots \ldots \ldots \ldots \ldots \ldots \ldots \ldots$ & 26.0 & 25.8 & 26.1 & 25.8 \\
\hline \multicolumn{5}{|l|}{ Kaikkien keskiarvo } \\
\hline Average ......................... & 25.6 & 25.6 & 26.4 & 25.6 \\
\hline
\end{tabular}

P e r k a s t a p p io

Koko saaliin keskimääräiseksi perkaustappioksi saatiin $25.6 \%$. Isojen muikkujen perkaustappiot vaihtelivat $20.7 \%$ :sta $32.3 \%$ :iin keskimääräisen tappion ollessa $25.6 \%$. Poikkeavan korkeita perkaustappioista esiintyi syyskuussa, jolloin se oli Konneveden isolla muikulla noin $29 \%$ ja Niiniveden isolla muikulla noin $32 \%$ (taulukko 6). Nämä poikkeuksellisen suuret perkaustappiot aiheutuivat mädistä, mikä ei vielä silloin ollut talteenotettavissa. Keskikokoisten muikkujen perkaustappio vaihteli $24.2 \%$ :sta $27.2 \%$ :iin, keskimääräisen perkaustappion ollessa $25.6 \%$. Pienten muikkujen perkaustappio vaihteli $24.9 \%$ ja $28.5 \%$ välillä keskimääräisen perkaustappion ollessa $26.4 \%$. TURPEINEN ja RoINE (1967) ruoka-aine-taulukossa on muikun perkaustappioksi ilmoitettu $30 \%$ (taulukko 6). 


\section{Yhteenveto}

Työn tarkoituksena oli selvittää muikun tuoresäilyvyyttä, kokojakautumaa ja perkaustappioita. Muikut säilyivät kauppakuntoisina $+4^{\circ} \mathrm{C}$ :ssa $24-$ 36 tuntia ja $+10^{\circ} \mathrm{C}$ :ssa alle 24 tuntia. Kalat olisi siis saatava kalastajalta jalostuslaitokseen välittömästi ja kuljetus olisi järjestettävä jäähdytetyssä tilassa tai kalat olisi jäitettävä.

Mikrobiologinen pilaantuminen eteni aina rasvojen pilaantumisen edellä. TBA-luku ei soveltunut laadun kriteeriksi tässä työssä.

Nuottapyynnillä saatiin kaikista kolmesta tutkimuskohteesta yli $60 \%$ saalista 10-16 g:n muikkua muiden kokoryhmien jäädessä vähäisiksi. Tämä kokoryhmä soveltuu hyvin jalostusraaka-aineeksi. Keskimääräinen perkaustappio oli $25.6 \%$.

Kiitokset. Tätä tutkimusta ovat tukeneet Suomen Luonnonvarain Tutkimussäätiö, Savon Taimen Oy, Rautalammin kunta ja sikäläiset kalastajat.

\section{KIRJALLISUUSLUETTELO}

Gyllenberg, H., LAine, J. \& Niemel.̈, S. 1966. Elintarvikkeiden mikrobiologian laboratorioopas: 68-69. (Julk.) Elintarviketutkijain Seura r.y., Helsinki.

HeıкKinen, J. 1960. Suomen kalansaalistilasto vuodelta 1959. Maataloushallituksen Kalataloudellinen tutkimustoimisto. Monistettuja julkaisuja no 11:26-42.

Нглтгкка, N. 1967. Kalansaalis, kalastajat ja kalastuksessa käytetyt veneet sekä pyynti rekisteriöidyillä aluksilla Suomessa vuosina 1964 ja 1965. Suomen Kalatalous 28: 6-10.

_ - 1969. Kalansaalis, kalastajat, kalastuksessa käytetyt veneet, pyynti rekisteröidyillä aluksilla sekä kotimaisen kalan jalostus ja kauppa Suomessa vuonna 1966. Suomen Kalatalous 41: 17-37.

JäRvI, T. H. 1919. Muikku ja muikkukannat. 1. Keitele. Suomen Kalatalous 5: 5-68.

- - 1947. Uber den Kleinmaränenbestand (Coregonus albula L.) in dem See Vesijärvi. Suomen Kalatalous 19.

MesstorfF, J. 1954 a. Untersuchungen über den Totenstarreverlauf bei Seefischen unter Berücksichtigung seiner Bedeutung für die Haltbarkeit und Qualitätserhaltung. Diplomarbeit, Math. Nat. Fak. Univ. Hamburg, Germany. (Ref.: Fish as Food 1961. 1: 403. New York).

- -1954 b. Über den Totenstarreverlauf einiger Seefischarten. Kurze Mill. Inst. Fischereibiol. Unib. Hamburg, 5: 1-21. (Ref.: Fish as Food 1961. 1:403. New York.).

NıккıLÄ, O. E., Mäцккі, Y. \& Mannola, R. 1971. Muikku täyssäilykkeiden raaka-aineena. VTT, Tiedotussarja IV, Kemia, 14 p.

Nissınen, T. 1972. Mätitiheys ja mädin eloonjääminen muikun (Coregonus albula L.) kutupaikoilla Puruvedessä ja Oulujärvessä. Riista- ja kalatalouden tutkimuslaitoksen kalantutkimusosaston tiedonantoja 1: 89-100.

SeppovaArA, O. 1969. Ison-Saimaan kalat ja kalastus. Suomen Kalatalous 38: 151-153.

Shewan, J. M. 1970. Chem. Ind. 6. Bacteriological Standards for Fish and Fishery Products. SutelA, J. 1968. Kalansaalis vuonna 1967. Suomen Kalastuslehti 8: 212-213.

- -1970 . Suomen kalansaalis vuonna 1969. Suomen Kalastuslehti 8: 236-238.

Turpeinen, O. \& Roine, P. 1967. Ruoka-ainetaulukko 38-39. Otava, Helsinki.

YU, T. C. \& Sinnhuber, R. O. 1957. 2-Thiobarbituric Acid Method for the Measurement of Rancidity in Fishery Products. Food Technol. 11, 2: 104-108.

Käsikirjoitus saapunut 2.5.1975. 